\title{
Las Cargas: Characterization and Prehistoric Use of a Southern Andean Obsidian Source
}

\author{
Laura Salgán, ${ }^{1, *}$ Raven Garvey, ${ }^{2}$ Gustavo Neme, ${ }^{1}$ Adolfo Gil, ${ }^{3}$ Martín Giesso, ${ }^{4}$ Michael D. Glascock, ${ }^{5}$ \\ and Víctor Durán ${ }^{6}$ \\ ${ }^{1}$ Departamento de Antropología, Museo de Historia Natural de San Rafael-CONICET/IANIGLIA, Mendoza, Argentina \\ ${ }^{2}$ Department of Anthropology, University of Michigan, Ann Arbor, Michigan \\ ${ }^{3}$ Departamento de Antropología, Museo de Historia Natural de San Rafael-CONICET/IANIGLIA and Universidad Nacional de Cuyo, Mendoza, Argentina \\ ${ }^{4}$ Department of Anthropology Northeastern Illinois University, Chicago, Illinois \\ ${ }^{5}$ Research Reactor Center, University of Missouri, Columbia, Missouri \\ ${ }^{6}$ Laboratorio de Paleoecología Humana, Universidad Nacional de Cuyo-CONICET, Mendoza, Argentina
}

\author{
Correspondence \\ *Corresponding author; E-mail: \\ mlaurasalgan@gmail.com. \\ Received \\ 19 June 2014 \\ Revised \\ 1 October 2014 \\ Accepted \\ 3 October 2014 \\ Scientific editing by Gary Huckleberry \\ Published online in Wiley Online Library \\ (wileyonlinelibrary.com). \\ doi 10.1002/gea.21502
}

\begin{abstract}
The importance of obsidian from the northern Patagonian source at Las Cargas is reflected in its early use ( $\sim 8000$ years B.P.) and extensive geographic diffusion but is nonetheless surprising in light of the source's high altitude (located in the Andes Cordillera), which makes it both difficult to access under ideal conditions and inaccessible for much of the year. Prehistoric use of the Las Cargas source can inform us about mobility, subsistence choices, economics of stone consumption, trade, and territoriality. Here we present the results of various lines of evidence (surface survey, X-ray fluorescence and instrumental neutron activation analyses, artifact morphometry, and obsidian hydration dating) used to characterize obsidian from Las Cargas and its prehistoric use during the Holocene. Results indicate that Las Cargas obsidian occurs at the source as blocks and nodules, which are chemically homogeneous and of variable quality. Use of the source was nearly continuous through time, and the primary knapping activities performed there were the production of blanks and preparation of cores. (c) 2015 Wiley Periodicals, Inc.
\end{abstract}

\section{INTRODUCTION}

Obsidian studies in southern Mendoza Province, Argentina, began in the mid-1990s with an analysis of the geochemical composition of material from the source at El Maule (Figure 1). Subsequent comparisons of these data were made to the geochemical signatures of obsidian artifacts from a handful of the region's archaeological sites (Seelenfreund et al., 1996). The potential of such obsidian studies to reveal regional patterns of behavior was immediately obvious, and so began a systematic effort to locate and characterize other sources in southern Mendoza and to map their archaeological distributions (Durán et al., 2004; De Francesco et al., 2006; Barberena et al., 2011; Giesso et al., 2011; Cortegoso et al., 2012). Intensive physical and geochemical surveys in the Mendoza and northern Neuquén Provinces have identified five sources-Las Cargas, El Maule, Laguna del Diamante, El Peceño, and Huenul; several of them have associated subsources (Figure 1; Durán et al., 2004; Giesso et al., $2011)$.

To understand prehistoric use of these five sources, rigorous sampling of archaeological materials was initiated. More than 700 obsidian artifacts from 61 archaeological sites in the region have been analyzed to date (Giesso et al., 2011;Cortegoso et al., 2012). On the one hand, these data present predictable patterns in which assemblages of archaeological obsidians tend to be dominated by material from the source to which they are closest in space (Giesso et al., 2011; Cortegoso et al., 2012). On the other hand, the archaeological data are somewhat counterintuitive, namely in the apparent preference for Andean sources (Las Cargas, El Maule, and Laguna del Diamante) over those located on the adjacent plains (El Peceño and Huenul) despite difficulties of access posed by altitude, terrain, and seasonality. Nonetheless, the data indicate early use and long-distance transport of Andean source materials (Barberena et al., 2011; Giesso et al., 


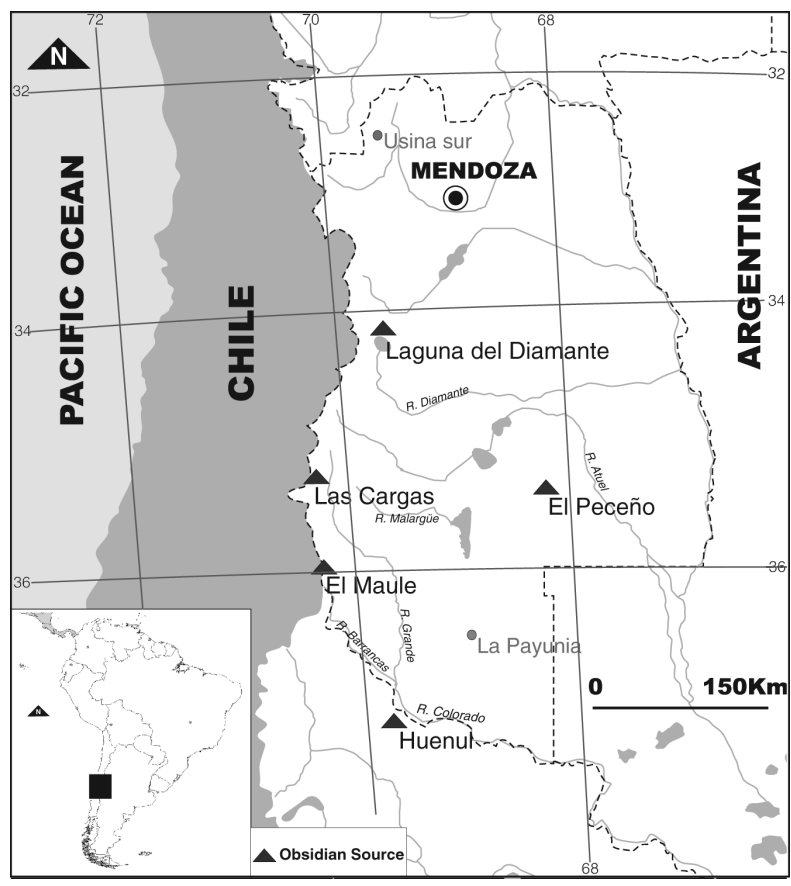

Figure 1 Location of obsidian sources in southern Mendoza Province, Argentina.

2011; Cortegoso et al., 2012), particularly for obsidian from Las Cargas.

Obsidian from Las Cargas has been recovered both in contexts predating $8000{ }^{14} \mathrm{C}$ yr B.P. and in a majority $(68 \%)$ of the archaeological sites sampled, indicating a broad temporal and geographic distribution. The Las Cargas source is located 2500-3000 meters above sea level (masl) on the Argentina-Chile border. High snow accumulation during winter and the absence of firewood make this area a hard place to live and accessible only between late spring and early fall. An absence of roads in this part of the Andes continues to limit access today.

Studies indicate that Las Cargas obsidian is the dominant type found at archaeological sites along the western slopes of the Andes in central Chile (Durán et al., 2004, 2012; de Francesco et al., 2006; Giesso et al., 2011 2004 Cortegoso et al., 2012). Preliminary lithic morphometric analyses of obsidian use in La Payunia, a volcanic region in southernmost Mendoza (Figure 1; Salgán, Gil, $\&$ Neme, 2012, 2014), confirm the broad geographic distribution of Las Cargas obsidian. They also demonstrate that prehistoric people may have obtained this obsidian by both direct and indirect means, and suggest that there may have been well-established routes of circulation of this and other obsidian throughout the region. Moreover, obsidian hydration studies conducted over the past five years help to refine the chronology of use and suggest early exploitation of the source (Garvey, 2012, 2015; Garvey et al., 2013).

These trends highlight both the importance of Las Cargas obsidian and the need to enhance our knowledge of the source by creating a more precise chemical characterization, conducting a detailed study of technologies used on obsidian from Las Cargas, and establishing tighter chronological control through both radiocarbon and obsidian hydration dating. The goals of the current work are as follows: (1) to describe the availability of Las Cargas obsidian in terms of size and quality of available flows/blocks/nodules, as well as their spatial distributions; (2) to identify the geochemical variability of the source; (3) to characterize prehistoric use of the source by identification of reduction stages represented in the surface record; and (4) to track changes in the use of the source through time.

\section{CHARACTERIZATION OF THE SOURCE: MATERIALS AND METHODS}

We have employed four lines of inquiry to characterize the Las Cargas source: (1) extensive archaeological survey of Las Cargas locality and adjacent areas to identify the physical boundaries of the source; (2) geochemical analyses (X-ray fluorescence and neutron activation) of materials from Las Cargas and possible subsources; (3) morphometric analyses of archaeological artifacts found at the Las Cargas source and comparison of these to regional archaeological trends; and (4) obsidian hydration analyses of materials from the source and comparison of these to regional archaeological trends. Each method is described below.

\section{Survey}

Two attempts to locate and characterize the Las Cargas source were undertaken by the Anthropology department of the Museo de Historia Natural de San Rafael in the summers of 2008 and 2011 . Location of the source was eventually made possible with the assistance of local puesteros (pastoralists) who guided researchers to the source and provided additional information regarding the location of obsidian blocks and outcrops.

Once the source was located, its areal extent and intra-source variability were determined through systematic survey, combined with a limited transect survey across parts of the site (Figure 2). Because no infrastructure currently exists in the area surrounding the site $\left(\sim 20 \mathrm{~km}^{2}\right)$, the survey was conducted on horseback. Because of the source's proximity to the Chilean border 

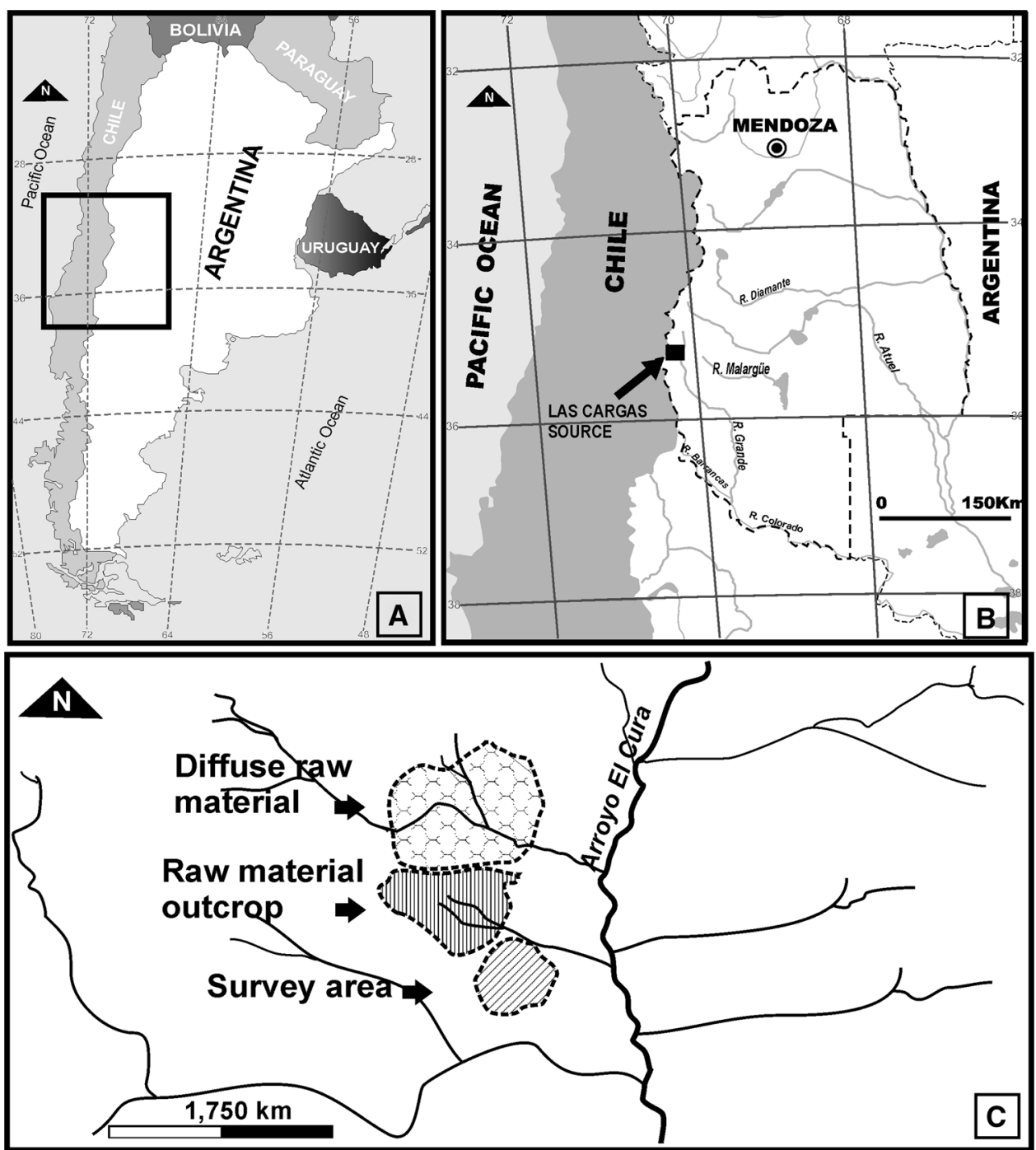

Figure 2 Location of Las Cargas source and survey area. (A) Map of mid-western Argentina. (B) Location of obisidian source. (C) Surveyed area in Las Cargas source.

$(\sim 2 \mathrm{~km})$, it was not feasible to survey the western slope of the Andes. Additional outcrops are likely to exist in Chile.

\section{Geochemical Analyses}

We selected for trace element analysis 50 samples from the transect survey described above. Samples were chosen based on gross physical appearance in an attempt to capture all possible variability within the source. Artifacts, cores, and nodules of various sizes and quality were included. The samples were analyzed by both $\mathrm{X}$ ray fluroresence (XRF; $n=91$ ) and instrumental neutron activation analysis (INAA; $n=17$ ) at the University of Missouri Research Reactor (MURR).
INAA offers excellent sensitivity, precision, and accuracy for a large number of elements, and it can be used to analyze bulk samples ranging from very large (e.g., several grams) to very small (e.g., $5 \mathrm{mg}$ ). Although INAA is the most reliable and accurate of the two methods (employed in this study) for most elements, it generally requires that a portion of the artifact be removed (by sawing or other means) to produce a sample that can be made radioactive. XRF can be performed non-destructively, and it is both rapid and inexpensive. XRF offers good sensitivity and accuracy for several trace elements (e.g., Rb, Sr, Y, Zr, and $\mathrm{Nb}$ ), identified by Shackley $(1998,2005)$ as important for discriminating between obsidian sources. However, XRF is primarily a surface technique rather than a bulk method, and it may yield inconclusive results when 


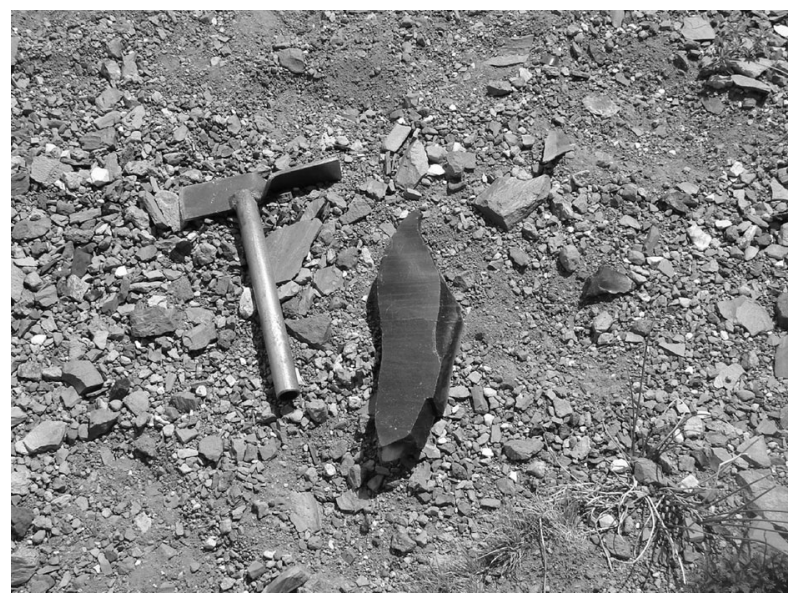

Figure 3 Example of core and flaking debris on surface.

the samples are small, thin, or irregularly shaped and when the chemical compositions are similar for the limited number of elements measured by XRF.

The INAA procedures for quantitative analysis of elements in obsidian at MURR have been described previously (Glascock, Braswell, \& Cobean, 1998). A total of 27 elements was measured in the current study, including $\mathrm{Al}, \mathrm{Ba}, \mathrm{Cl}, \mathrm{Co}, \mathrm{Cs}, \mathrm{Dy}, \mathrm{Eu}, \mathrm{Fe}, \mathrm{Hf}, \mathrm{K}, \mathrm{La}, \mathrm{Lu}, \mathrm{Mn}, \mathrm{Na}, \mathrm{Nd}$, $\mathrm{Rb}, \mathrm{Sb}, \mathrm{Sc}, \mathrm{Sm}, \mathrm{Sr}, \mathrm{Ta}, \mathrm{Tb}, \mathrm{Th}, \mathrm{U}, \mathrm{Yb}, \mathrm{Zn}$, and Zr.

$\mathrm{X}$-ray fluorescence analyses were performed using a hand-held XRF spectrometer made by Bruker Corporation (Tracer III-V, serial number K0577). The pin-diode based spectrometer was operated at $40 \mathrm{keV}$ with a current of $17 \mathrm{~mA}$. Using measurement times of 180 seconds, 13 elements were measured in most samples, including $\mathrm{K}, \mathrm{Ti}, \mathrm{Mn}, \mathrm{Fe}, \mathrm{Zn}, \mathrm{Ga}, \mathrm{Rb}, \mathrm{Sr}, \mathrm{Y}, \mathrm{Zr}, \mathrm{Nb}, \mathrm{Pb}$, and Th. Calibration of the XRF was established by measuring a suite of obsidian specimens from 40 sources previously characterized by INAA, inductively coupled plasma-mass spectrometry, and XRF (Glascock \& Ferguson, 2012). After the raw data are collected, bivariate plots are generated for the $\mathrm{Rb}-\mathrm{Sr}, \mathrm{Rb}-\mathrm{Zr}$, and $\mathrm{Sr}-\mathrm{Zr}$, which we identified as the most diagnostic elements measured by XRF in this study. A $90 \%$ confidence or probability ellipse is drawn around each group to indicate the range of distribution. In some cases, ellipses may partially overlap, which makes it difficult to determine the precise source/subsource. When the latter occurs, the option of collecting the more discriminating data from INAA is possible.

\section{Artifact Morphometric Analyses}

The surface survey at Las Cargas produced lithic artifacts (Figure 3 ) that were analyzed to better understand stone provisioning and technological strategies evident
Table I Survey transects and surface sample information.

\begin{tabular}{lcccl}
\hline Transect & $\begin{array}{c}\text { Survey Area } \\
\left(\mathrm{m}^{2}\right)\end{array}$ & $\begin{array}{c}\text { Number }(\mathrm{N}) \\
\text { of Artifacts }\end{array}$ & $\begin{array}{c}\text { Estimated } \\
\text { Abundance* }\end{array}$ & $\begin{array}{l}\text { Artifact } \\
\text { Density } \\
\left(\mathrm{N} / \mathrm{m}^{2}\right)\end{array}$ \\
\hline TR1 & $11,400 \mathrm{~m}^{2}$ & 52 & 51 & 0.0045 \\
TR2 & $5600 \mathrm{~m}^{2}$ & 28 & 27 & 0.005 \\
Total & $17,000 \mathrm{~m}^{2}$ & 80 & 78 & 0.0047 \\
\hline
\end{tabular}

*Sensu Hiscock (2002).

both at the source and in regional archaeological sites. Artifacts were collected from the surface following two transects that covered $17,000 \mathrm{~m}^{2}$, made up of $200 \mathrm{~m}^{2}$ units measuring $4 \mathrm{~m}$ (width) $\times 50 \mathrm{~m}$ (length, Table I) Along the first transect (TRl) we established 57 survey units, of which five contained no archaeological materials. Along the second transect (TR2) we established 28 units, one of which contained no archaeological materials. Techno-morphological analyses followed Aschero $(1975,1983)$ and included the following variables: typological class (Aschero \& Hocsman, 2004), maximum size ${ }^{1}$ (Aschero, 1975, 1983) and thickness, ${ }^{2}$ presence of cortex, completeness (whether whole or broken), number of flake removals on the dorsal surface, and intensity of use (Ingbar, 1994). ${ }^{3}$ To determine the number of artifacts in each collection we used the minimum number of flakes, or MNF (sensu Hiscock, 2002), as well as tools, cores, and whole flakes.

\section{Obsidian Hydration Analyses}

The 2011 expedition yielded 97 surface-collected obsidian samples from the lower portion of the Las Cargas source. Two transects guided specimen collection, one running approximately $150 \mathrm{~m}$ north-south and the other, $\sim 200$ m east-west, adjacent to one of several arroyos that run down the steep embankment to Arroyo El Cura (Figure 2C), east of the obsidian-bearing formation. The majority of the sample $(78 \%)$ consists of apparently modified specimens (i.e., exhibiting bulb of percussion, platform, dorsal flaking or other flake attributes). The remaining $22 \%$ does not appear to have been altered by humans and provides a baseline for hydration on

\footnotetext{
${ }^{1}$ Size was calculated using a grid of $40 \mathrm{~mm}$ rhomboidal cells: small $=0$ to $40 \mathrm{~mm}$, medium $=41$ to $80 \mathrm{~mm}$, large $=81$ to $120 \mathrm{~mm}$ and, very large $=$ greater than $121 \mathrm{~mm}$. The size of each artifact was determined relative to this grid rather than by precise quantification.

${ }^{2}$ The thickness of each artifact was calculated from the maximum thickness in millimeters, according ranks: plain $=$ less than $2.7 \mathrm{~mm}$; thick $=2.8$ to $5.4 \mathrm{~mm}$; very thick $=$ greater than $5.5 \mathrm{~mm}$. ${ }^{3}$ Index calculated from the ratio between the number of negative flake scars on the dorsal side of the flake and area (maximum width and length in millimeters). The result is expressed in the amount of negative flaking per square milimeter, synthesized as $\mathrm{e} / \mathrm{mm}^{2}$ (e = extractions).
} 


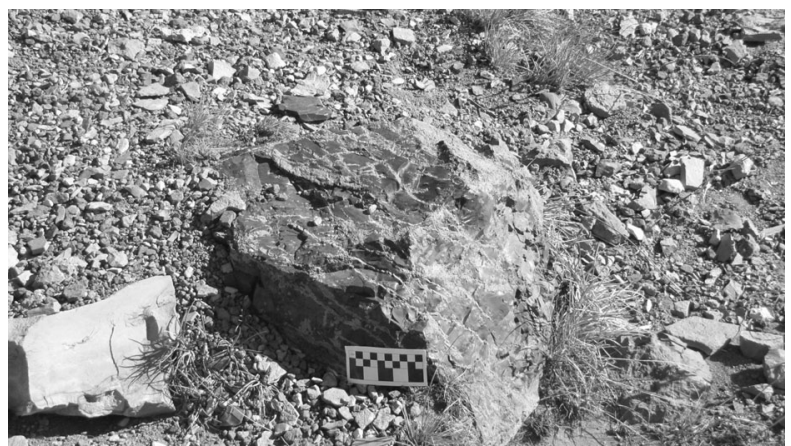

Figure 4 Block of obsidian in the outcrop zone.

geological specimens, giving insights into maximum hydration, degree of weathering, and natural variation in hydration rim thickness.

ArchaeoMetrics Obsidian Hydration Laboratory in Woodland, California, prepared the samples and measured their hydration rim thicknesses. Each specimen was cut using a lapidary saw and the extracted samples were mounted on microscope slides, which were then ground to an appropriate thickness $(30-50 \mu \mathrm{m})$ and viewed under a petrographic microscope. The technician used a micrometer to record three to ten measurements (depending on surface damage and weathering), which he averaged and provided in a spreadsheet that included each measurement plus each sample's mean rim value and standard deviation (SD). The mean rim values form the basis of the hydration analyses presented below.

\section{RESULTS}

\section{Location and Characterization of Available Vitreous Material}

Intensive physical and geochemical survey indicates that the primary source at Las Cargas is located on the border

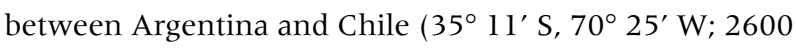
masl), on the bank of the Arroyo El Cura, a tributary of the Grande River (Figure 2). Obsidian of variable quality for tool production appears as both vitreous outcrops in a matrix of weathered ignimbrite (Figure 4) and as blocks and nodules distributed across a glacial formation composed of till (poorly sorted loose sand and gravel that includes blocks that lack abrasion). Pronounced erosion at the river's headwaters has exposed part of the outcrop and transported vitreous material $300 \mathrm{~m}$ downstream. The total area of the source is $\sim 1 \mathrm{~km}^{2}$ (Figure 2), although horseback survey indicates the presence of transported obsidian nodules along the bed of the Arroyo El Cura nearly $4 \mathrm{~km}$ downstream. The INAA results (Table II) indicate that Las Cargas has chemical properties that distinguish it from other sources in

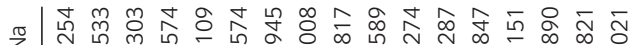

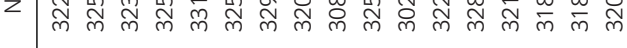

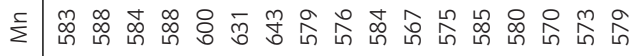

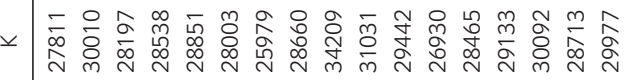

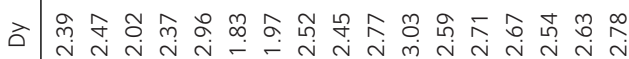

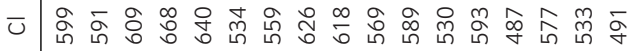

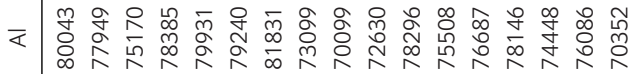

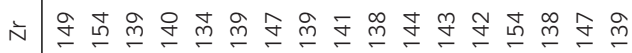

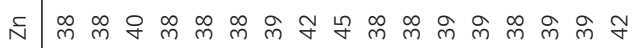

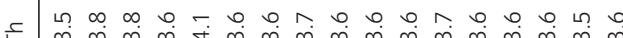

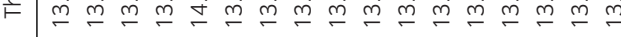

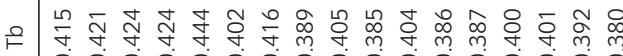

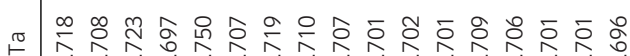

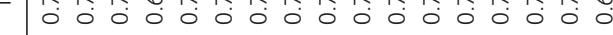
ท

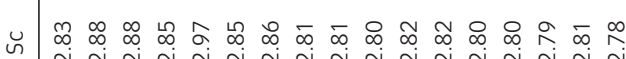

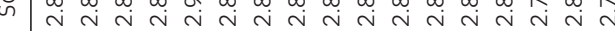

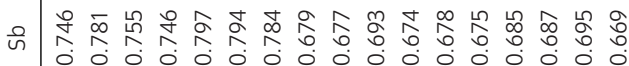

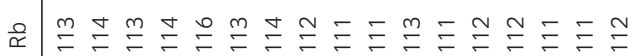

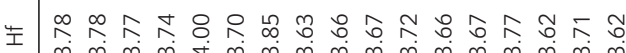

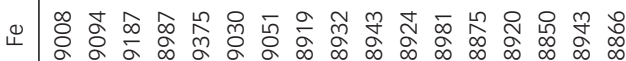

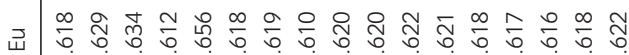

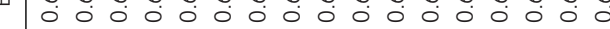

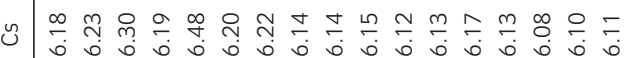

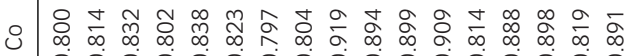

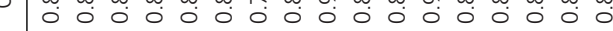

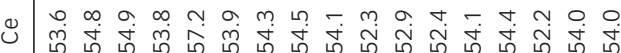
을 웅ำ

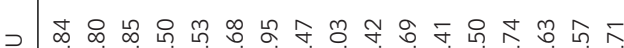

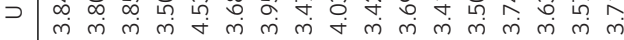
E 윤ํํำ

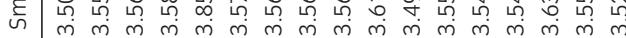

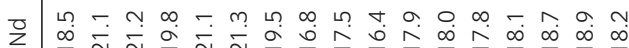
ᄀ

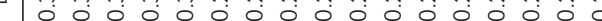

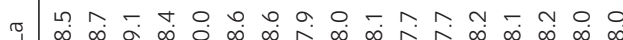

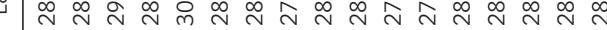

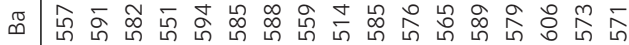
•

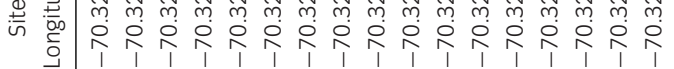

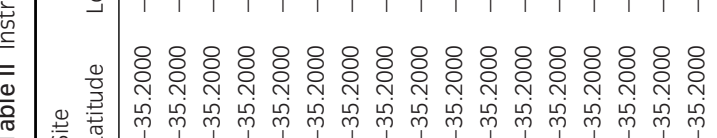




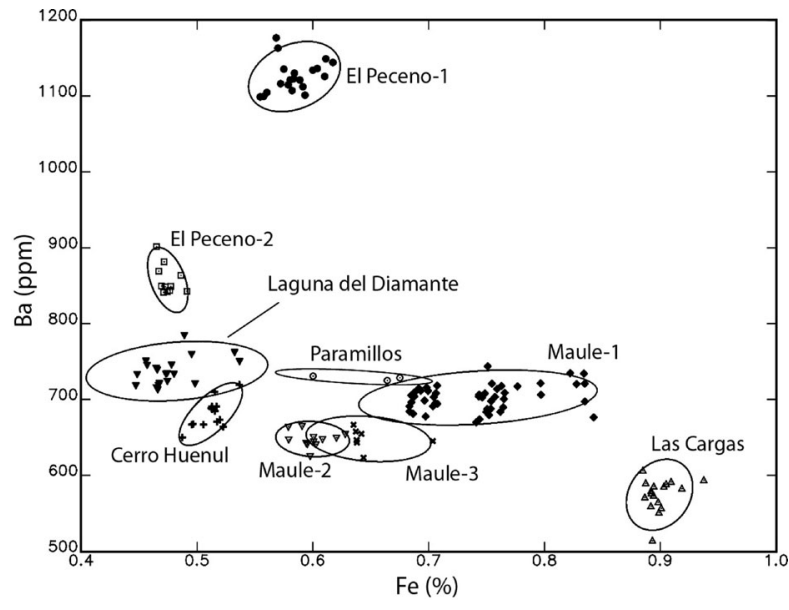

Figure 5 Comparison of $\mathrm{Fe}$ and $\mathrm{Ba}$ contents from regional obsidian sources and subsources.

southern Mendoza (Figure 5), given that it has the highest iron (Fe) content and the lowest barium (Ba) content in the region.

XRF analysis (Table III; Supplementary Table I) indicates that Las Cargas obsidian is best distinguished by $\mathrm{Sr}$, $\mathrm{Rb}$, and $\mathrm{Zr}$. It is important to note, however, that the geochemical composition of Las Cargas obsidian is very similar to that of subsource Arroyo Paramillos, associated with the source at Laguna del Diamante, $\sim 100 \mathrm{~km}$ north of Las Cargas (Durán et al., 2004; De Francesco et al., 2006). This overlap caused confusion among researchers in the region during the last 10 years (Giesso et al., 2011; Cortegoso et al., 2012). A preliminary characterization of Paramillos subsource, located more than $130 \mathrm{~km}$ to the north of Las Cargas in another volcanic field, showed a very similar chemical composition to Las Cargas, leading to incorrect assignment of some analyzed samples (Cortegoso et al., 2012). This mistake overestimated the influence of the Las Cargas source to the north in Mendoza province and to the west in Chile. However, more recent results of INAA indicate significant differences in their respective levels of Sr: Las Cargas has Sr values of 180-200 ppm (Table IV) while those at Arroyo Paramillos are 200-250 ppm. This difference in Sr values allows us to discriminate between both sources and reassign most of the samples originally assigned to Las Cargas to the Paramillos subsource.

Presently, results suggest that the Las Cargas source is the product of a single volcanic eruption. Both XRF and INAA indicate that the source is internally homogeneous, making it both physically and chemically well-defined, in contrast to the region's other sources which, with the exception of Huenul, all have multiple subsources (two or more) that complicate source designation of archaeolog-
Table III Mean and standard deviation (SD) in parts per million for geological samples $(n=91)$ from Las Cargas analyzed by X-ray diffraction.

\begin{tabular}{|c|c|c|c|}
\hline Element & Mean & & SD \\
\hline $\mathrm{Na}(\%)$ & 3.22 & \pm & 0.07 \\
\hline Al (\%) & 7.63 & \pm & 0.34 \\
\hline $\mathrm{Cl}$ & 577 & \pm & 50 \\
\hline K (\%) & 2.91 & \pm & 0.18 \\
\hline Sc & 2.83 & \pm & 0.05 \\
\hline $\mathrm{Mn}$ & 587 & \pm & 20 \\
\hline $\mathrm{Fe}(\%)$ & 0.90 & \pm & 0.01 \\
\hline Co & 0.85 & \pm & 0.05 \\
\hline $\mathrm{Zn}$ & 39.4 & \pm & 2.1 \\
\hline $\mathrm{Rb}$ & 113 & \pm & 1 \\
\hline Sr & 192 & \pm & 22 \\
\hline $\mathrm{Zr}$ & 143 & \pm & 6 \\
\hline $\mathrm{Sb}$ & 0.72 & \pm & 0.05 \\
\hline Cs & 6.18 & \pm & 0.09 \\
\hline $\mathrm{Ba}$ & 574 & \pm & 21 \\
\hline La & 28.3 & \pm & 0.6 \\
\hline $\mathrm{Ce}$ & 54.0 & \pm & 1.2 \\
\hline $\mathrm{Nd}$ & 18.9 & \pm & 1.6 \\
\hline $\mathrm{Sm}$ & 3.57 & \pm & 0.08 \\
\hline $\mathrm{Eu}$ & 0.62 & \pm & 0.01 \\
\hline $\mathrm{Tb}$ & 0.40 & \pm & 0.02 \\
\hline Dy & 2.51 & \pm & 0.33 \\
\hline $\mathrm{Yb}$ & 1.62 & \pm & 0.06 \\
\hline Lu & 0.29 & \pm & 0.03 \\
\hline $\mathrm{Hf}$ & 3.73 & \pm & 0.10 \\
\hline $\mathrm{Ta}$ & 0.71 & \pm & 0.01 \\
\hline Th & 13.7 & \pm & 0.1 \\
\hline U & 3.73 & \pm & 0.28 \\
\hline
\end{tabular}

Table IV Mean and standard deviation (SD) in parts per million for geological samples $(n=17)$ from Las Cargas analyzed by instrumental neutron activation analysis.

\begin{tabular}{lccc}
\hline Element & Mean & & $\mathrm{SD}$ \\
\hline $\mathrm{K}(\%)$ & 3.56 & \pm & 0.08 \\
$\mathrm{Ti}$ & 793 & \pm & 109 \\
$\mathrm{Mn}$ & 600 & \pm & 92 \\
$\mathrm{Fe}(\%)$ & 0.98 & \pm & 0.07 \\
$\mathrm{Zn}$ & 59 & \pm & 14 \\
$\mathrm{Ga}$ & 17 & \pm & 3 \\
$\mathrm{Rb}$ & 122 & \pm & 7 \\
$\mathrm{Sr}$ & 177 & \pm & 10 \\
$\mathrm{Y}$ & 15 & \pm & 2 \\
$\mathrm{Zr}$ & 119 & \pm & 8 \\
$\mathrm{Nb}$ & 8 & \pm & 1 \\
$\mathrm{Th}$ & 13 & & 2 \\
\hline
\end{tabular}

ical materials. The results presented here confirm work by De Francesco et al. (2006) and help resolve previous issues of discrimination between samples of Las Cargas and the Paramillos subsource of Laguna del Diamante. 
Table $\mathrm{V}$ Whole versus fractured artifacts from transects 1 and 2 .

\begin{tabular}{llcllr}
\hline Transect & Condition & Debitage & Tools & Core & Total \\
\hline TR1 & Whole & 42 & 2 & 3 & $47(90 \%)$ \\
& Fractured & 4 & 1 & - & $5(10 \%)$ \\
& & & & & \\
TR2 & Whole & 21 & 1 & - & $22(79 \%)$ \\
& Fractured & 6 & - & - & $6(21 \%)$ \\
& & & & & \\
\hline
\end{tabular}

Table VI Debitage-type frequencies per transect.

\begin{tabular}{lccc}
\hline Flake Form & TR1 & TR2 & Total \\
\hline Primary flake & - & - & - \\
Secondary flake & $2(4 \%)$ & & $2(3 \%)$ \\
Angular flake & $20(43 \%)$ & $12(44 \%)$ & $32(44 \%)$ \\
Flake with edge & $19(41 \%)$ & $9(33 \%)$ & $28(38 \%)$ \\
Edge resharpening flake & $2(4 \%)$ & - & $2(3 \%)$ \\
Flake core & $3(7 \%)$ & $6(22 \%)$ & $9(12 \%)$ \\
\hline
\end{tabular}

\section{Artifact Morphometrics}

The density of artifacts is greater along TR2, and the abundance of artifacts does not appear to be affected to a significant degree by fracture. The most frequent artifact class among the obsidian on both transects is knapping debris $(91 \%)$, followed by tools $(5 \%)$ and cores $(4 \%)$. On TR1, $90 \%$ of the collection lacks fractures (Table V). The condition is generally good without mechanical alterations but with presence of patinas (physical or chemical alterations, 60\%). Knapping debris is the most frequent artifact class $(91 \%)$ and consists largely of internal flakes (angular flake and with edge, 85\%), followed by external flakes (secondary and nodular, $11 \%$ ) and edge preparation flakes (4\%; Table VI). Knapping debris is characterized as predominantly very thick $(54 \% ; 0-2.7 \mathrm{~mm})$ and thick $(43 \% ; 2.8-5.4 \mathrm{~mm})$; flake size is predominantly large $(56 \% ; 81-120 \mathrm{~mm})$ followed by small $(0-40 \mathrm{~mm})$ and medium $(41-80 \mathrm{~mm})$ in equal proportions $(22 \%)$. Cortex is present on only two flakes and a nodular flake. Among the tools are three unifaces, two of which are very thick and one is plain and fractured; all are very large (greater than $121 \mathrm{~mm}$ ) and two exhibit patina. The cores $(n=3)$ are large and thick and none are exhausted; two have isolated flake removals and indeterminate form while the third is prismatic.

On TR2, 79\% of the artifacts are complete and the collection seems generally well preserved given that there are few signs of mechanical alteration and only $20 \%$ of the sample has patina. The most common artifact class is debitage, dominated by internal flakes (angular and with edge, $78 \%$ ), followed by the external flakes (nodular, 22\%). Knapping debris is characterized as
Table VII Descriptive statistics for density of waste flakes by $\mathrm{mm}^{2}$ from transects 1 and 2 .

\begin{tabular}{lccccccc}
\hline Sample & Number & Mean & Median & SD & Minimum & Maximum & Range \\
\hline TR1 & 44 & 0.93 & 0.63 & 0.89 & 0.096 & 4.30 & 4.21 \\
TR2 & 27 & 0.51 & 0.32 & 0.44 & 0.040 & 1.73 & 1.69 \\
\hline
\end{tabular}

Flakes produced from reactivation of edge (flat chips, reactivation and bifacial thinning flakes) are not considered in the calculation of this index.

predominantly very thick $(61 \% ;>5.5 \mathrm{~mm})$, followed by thick $(31 \% ; 2.8-5.4 \mathrm{~mm})$, and flat $(8 \% ; 0-2.7 \mathrm{~mm})$; most $(93 \%)$ are large $(81-120 \mathrm{~mm})$ and the rest medium $(7 \%$; 41-80 mm). All pieces lack cortex. The single tool is a relatively large, thick flake with a natural edge. No cores were observed.

The mean degree of reduction, or density of negative flake scars on the dorsal face of the debitage, is higher on TRl, which suggests that TR 1 flakes on average represent greater reduction. TRl also shows greater variability in the degree of reduction, as indicated by the high values of SD and range (Table VII).

Based on the results of these morphometric analyses, all stages of reduction, including edge resharpening, took place along TRl. It is noteworthy that both transects include a high frequency of large, thick internal flakes, and a low frequency of primary and secondary flakes, and cores. This trend supports the idea that in the sampled areas are where preforms, and to a lesser extent cores, were produced. The general lack of primary flakes may owe to the form of the raw material at the site, which is generally without cortex.

\section{Obsidian Hydration}

Recently, we developed a preliminary model of age estimation for Las Cargas obsidian using hydration data (Garvey et al., 2013). Based on 44 hydration rim-radiocarbon pairs from 10 stratified archaeological sites across southern Mendoza Province, the equation that best predicts the known ages of obsidian samples is

$$
t=1848.7 x-61.21
$$

where $\boldsymbol{t}$ is radiocarbon years before 1950 and $\boldsymbol{x}$ is the hydration rim thickness in microns $(\mu \mathrm{m})$.

By this equation, and given the 2011 surface sample from Las Cargas, the source is estimated to have been used fairly continuously $\sim 10,350-1800{ }^{14} \mathrm{C}$ yr B.P. (Figure 6). There is an apparent gap in its use $\sim 7800-$ $6700{ }^{14} \mathrm{C}$ yr B.P. (Figure 7), consistent with a trend observed in the region's number of radiocarbon dates, which decline significantly during the middle Holocene (Neme \& Gil, 2008, 2009, 2012; Méndez et al., 2015; 


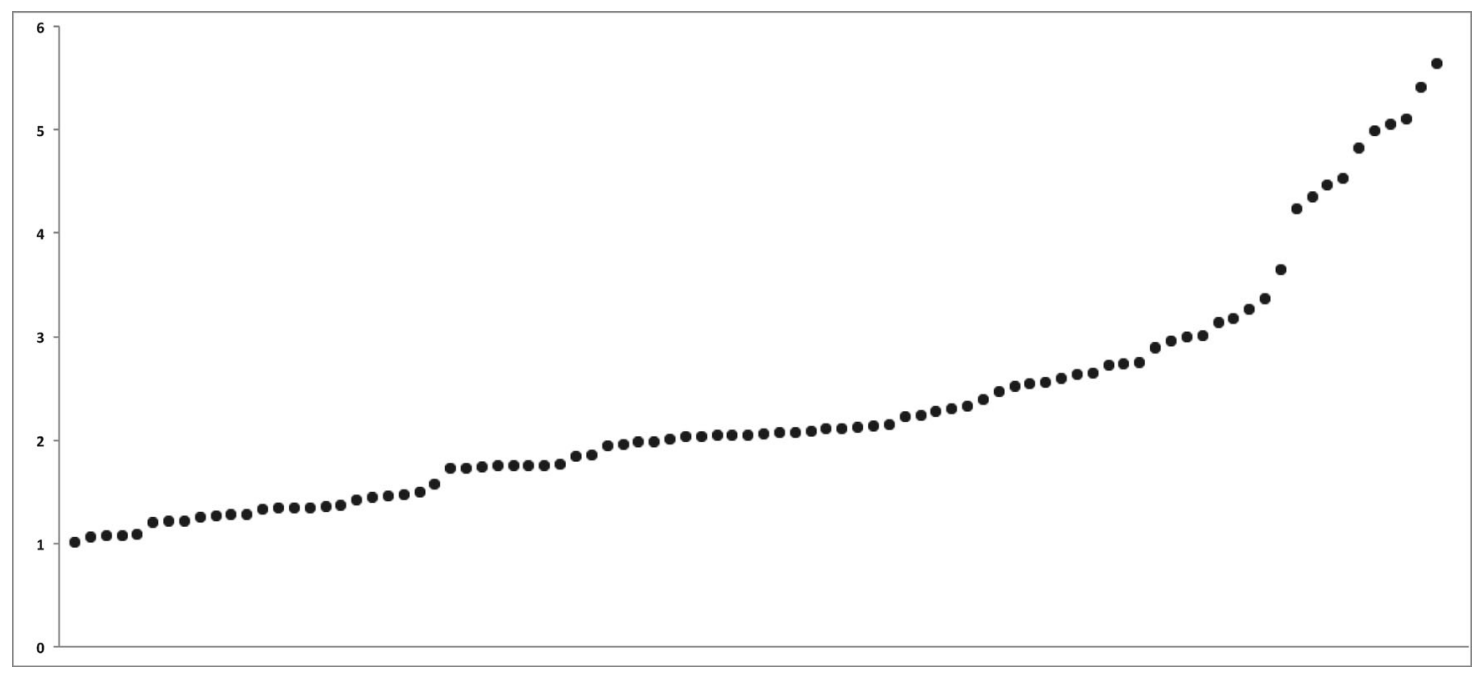

Figure 6 Hydration rim measurements $(n=97)$ from the 2011 surface sample arranged sequentially from smallest to largest.

cf. Garvey, 2012). The estimate of the earliest source use is also consistent with that observed for Las Cargas obsidian in stratified sites in southern Mendoza $(6.01 \mu \mathrm{m}$ $=11,050{ }^{14}$ C yr B.P.).

It should be noted that Equation (1) is based on rim measurements uncorrected for effective hydration temperature. Obsidian hydration is governed in part by ambient temperature and accounting for effective hydration temperature-the temperature that characterizes the hydration effects of temporal variations in temperature (Rogers, 2007)—should improve hydration model fit. Comparison of 12 potential hydration models for Las Cargas obsidian indicate that uncorrected equations outperform those based on temperature-corrected rim values (Garvey et al., 2013), if only by a slight margin. That is, corrected and uncorrected equations differ in their predictive accuracy by an average of only $2.4 \%$ (based on their respective normalized root mean squared deviations). Given that hydration slows as temperature decreases, temperature-corrected rates should outperform uncorrected ones at this altitude (Rogers, 2009). It remains unclear if the fact that they do not owes to the quality of available weather data, or to temperature simply not affecting hydration over the range of elevations used to generate the equation (see Garvey et al., 2013 for further discussion). Understanding this will be crucial both in refining the hydration equation proposed for Las Cargas and in more precisely defining patterns

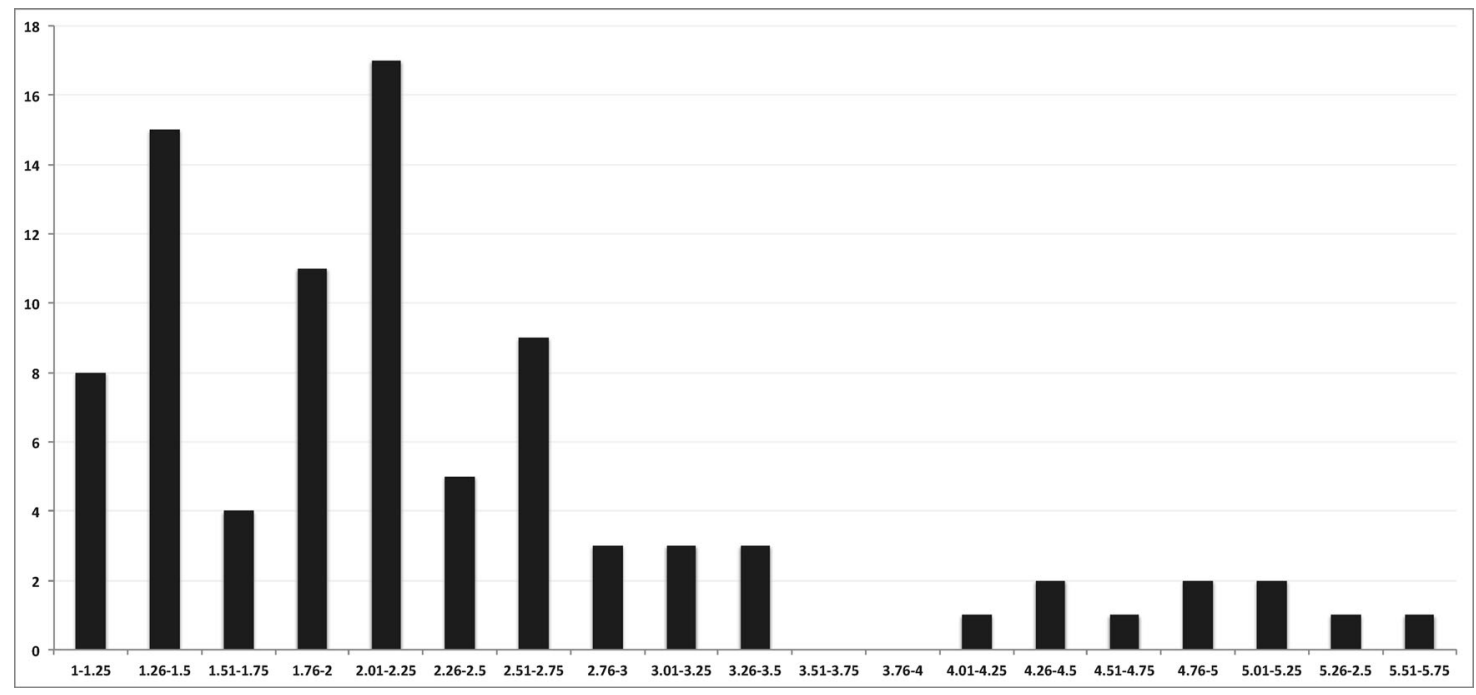

Figure 7 Histogram showing the frequencies of particular hydration rim measurements ( $n=97)$ among samples collected in 2011. 
of source use (Tripcevich, Eerkens, \& Carpenter, 2012). Nonetheless, the high degree of correspondence between the hydration-based and radiocarbon dates from the region's stratified sites supports the preliminary equation despite no correction Still, it is worth noting that because the portion of the quarry under consideration is $\sim 3000$ masl, the age estimates provided here may be conservative, underestimating actual artifact ages.

Independent of these age estimates, the distribution of rim thickness values provides insights into patterns of source use and can also be used to better understand the distribution of obsidian in the region's archaeological record. The rim values in this sample range $1.0-5.6 \mu \mathrm{m}$, although $82 \%$ are $1-3 \mu \mathrm{m}$ (mean $=2.3, \mathrm{SD}=1.1$, minimum $[\min ]=1.0$, maximum $[\max ]=5.6)$. The high proportion of rims $1-3 \mu \mathrm{m}$ is echoed in stratified sites across southern Mendoza Province; in the available archaeological sample, $72 \%$ of all measured Las Cargas rim values fall between 1 and $3 \mu \mathrm{m}$ (mean $=2.4, \mathrm{SD}=0.88$, $\min =0.97, \max =6.0$ ). The consistency between the site data and quarry data suggests more intensive use of the sources after $\sim 5500{ }^{14} \mathrm{C}$ yr B.P., with a peak between $\sim 4100$ and $\sim 3600{ }^{14} \mathrm{C}$ yr B.P.

A final observation bears mentioning here. Las Cargas obsidian appears to hydrate slowly relative to other welldocumented obsidian sources in both the northern and southern hemispheres, for example, Coso in California (Rogers \& Yohe, 2011) and southern Peru (Eerkens et al., 2008). For example, a $4 \mu \mathrm{m}$ hydration rind at Las Cargas using Equation (1) generates an age of $7334{ }^{14} \mathrm{C}$ yr B.P. whereas a $4 \mu \mathrm{m}$ hydration rind at Coso $=683{ }^{14} \mathrm{C}$ years B.P. (Rogers \& Yohe, 2011). Slow hydration rates at Las Cargas are also indicated among a sample of the region's projectile points. A distinctive projectile point form associated with early archaeological components in southern Mendoza has a maximum rim value of $4.1 \mu \mathrm{m}$ when made on Las Cargas obsidian and a maximum rim value of $12.2 \mu \mathrm{m}$ when made on El Maule obsidian (Garvey, 2012; Garvey et al., 2013). The dates calculated for these rim values by each source's preliminary hydration equation are, respectively, $\sim 7500$ and $\sim 11,700{ }^{14} \mathrm{C}$ yr B.P., which correspond to the earliest components in southern Mendoza. Furthermore, no obsidian sample from either the source or regional archaeological contexts has a rim value larger than $6.1 \mu \mathrm{m}$, estimated by Equation (1) to date $\sim 11,050{ }^{14} \mathrm{C}$ yr B.P., which is consistent with the accepted date of earliest occupation in southern Mendoza.

\section{DISCUSSION}

Primary obsidian sources are typically localized, often in inhospitable, hard-to-reach places. Among prehistoric people who made tools from obsidian, this uneven distribution required a deliberate strategy for exploitation (Garvey, 2015). Two strategies people used to solve the problem of obsidian's patchy distribution are express trips to the sources (direct procurement) and trade (indirect procurement; Halstead \& O'Shea, 1984). Distinguishing direct from indirect procurement remains problematic, however, given that neither the presence of nonlocal raw materials nor the total distance between archaeological site and source is a reliable measure of how the material arrived at the site (Hughes, 1994; Shackley, 2005; King, Hildebrandt, \& Rosenthal, 2011; Beck \& Jones, 2011; Moratto, 2011).

Artifact morphometric analyses of samples collected at the Las Cargas source were unable to clarify whether end consumers or distributors (or both) were making visits to the site or whether patterns in acquisition changed through time. Preform or blanks production and, to a lesser extent, preparation of cores were frequent activities at the source, although such cobble-testing and minimal preparation for transport could represent either deferred personal use or trade (Binford \& O'Connell, 1984; Elston, 1992; Shackley, 2005). The data do also indicate that all stages of reduction are represented in the assemblage, which might suggest at least some production by end consumers.

While the primary means of procurement remains unclear at this point, the importance of Las Cargas obsidian in prehistoric tool manufacture led to its transportwhether direct or indirect-over great distances. Trace element analyses of materials from both the source and archaeological sites in southern Mendoza show that Las Cargas obsidian was transported hundreds of kilometers from the source (at least $300 \mathrm{~km}$ north to Usina Sur in Uspallata; Giesso et al., 2011; Cortegoso et al., 2012; Neme $\&$ Gil, 2012), and distributed over an area of more than $100,000 \mathrm{~km}^{2}$ (Mendoza Province and central Chile). Samples of Las Cargas obsidian from radiocarbon-dated archaeological contexts in southern Mendoza indicate that it was used early $\left(\sim 8000{ }^{14} \mathrm{C}\right.$ yr BP) and that its use increased through time; hydration equations recently derived and presented here confirm early and nearly continuous use through time (Garvey, 2012; Garvey et al., 2013).

Like use intensity, transport distance appears to have increased through time, which might indicate a transition from direct to indirect procurement (Neme \& Gil, 2012). Technological studies from La Payunia (170-200 km from the source), for example, suggest that procurement of Las Cargas obsidian was likely indirect during the Late Holocene given the scarcity of tools, artifacts' small size, and heterogeneous spatial distribution (Salgán, Gil, \& Neme, 2014). 
Distinguishing direct from indirect procurement is very important to understanding stone-consumption behavior (Salgán, Gil, \& Neme, 2012, 2014; Nadooshan et al., 2013; Bonomo et al., 2014; Garvey, 2015; Summerhayes et al., 2014), yet the evidence has been inconclusive to this point. Nonetheless, temporal-spatial patterns of obsidian use in southern Mendoza have informed important discussions regarding prehistoric settlement and landscape use, subsistence, and territoriality (Neme, 2007; Neme \& Gil, 2008, 2012; Barberena et al., 2011; Giesso et al., 2011; Cortegoso et al., 2012; Garvey, 2012, 2015; Salgán, Gil, \& Neme, 2012).

Despite difficulty in access, Las Cargas was the most used obsidian source in the region. In fact, the Andean sources at Las Cargas and Laguna del Maule together account for the vast majority of prehistoric obsidian used in southern Mendoza. This is a topic of much interest and discussion (e.g., Giesso et al., 2011; Garvey, 2012) given that there are several obsidian sources on the plains that offer nodules of similar size and quality that are both easier to access and available year-round. Clearly, more work is needed in this regard, including expansion of regional surveys along the entire Grande River basin to identify all possible locations of secondary sources from Las Cargas.

\section{CONCLUSIONS}

As the most heavily exploited obsidian source in the region, study of Las Cargas using multiple lines of evidence is essential to our understanding of prehistoric huntergatherers in northern Patagonia. The current research clarified the surface availability of raw material in the form of blocks and nodules suitable for knapping and confirmed the presumed richness of the source based on archaeological collections. The size and shape of raw materials available on the source's surface, which are generally large and free of cortex, might explain the lack of core-preparation debris at the source and the scarcity of cores at known archaeological sites. However, the nearly continual use of the Las Cargas throughout the Holocene relative to the few techno-morphological studies of this material in the region's archaeological sites obscure prehistoric modes of procurement and use.

New geochemical characterizations of the source helped clarify previous confusion of two sources and to identify a new subsource. The latter raises new questions and requires expansion of our discussions of raw material procurement, which will surely be clarified by more-detailed studies of regional lithic technologies from radiocarbon-dated contexts in southern Mendoza. More- over, future studies should also be geared toward refining the obsidian hydration rate and detection of other subsources.

This work represents the first effort to characterize a northern Patagonian obsidian source using multiple lines of evidence, which allows us to better understand the variables that may have affected raw material availability at this source. As mentioned, of all known obsidian sources in the region, Las Cargas appears to have been used earliest and most often and distributed over the widest area; in one way or another, many of the region's prehistoric behavioral strategies may be represented at this site. Understanding prehistoric use of this source, then, will help us understand human processes that took place in the region over the past 8000 years.

We thank the International Center for Earth Sciences of Malargüe for the loan of the field boxes Pteroa, and Don José "Pepe" Selpúlveda and family for their collaboration in fieldwork. We also thank Ramiro Barberena for his help with survey records. We also thank the University of California, Davis Office of Graduate Studies and Department of Anthropology for funding Raven Garvey's participation in the 2011 Las Cargas expedition and subsequent obsidian hydration analyses. Fieldwork and laboratory analyses were funded by Consejo Nacional de Investigaciones Científicas y Técnicas and Agencia Nacional de Investigación Científica y Tecnológica (PICT 2012 -1015). The National Science Foundation (grant no. 1110793) supported work conducted in the Archaeometry Lab at MURR. Lastly, we would like to thank the editors and two anonymous referees for useful comments.

\section{REFERENCES}

Aschero, C.A. (1975). Ensayo para una clasificación morfológica de artefactos líticos aplicados a estudios tipológicos comparativos. Unpublished manuscript. Report to CONICET, Buenos Aires.

Aschero, C.A. (1983). Ensayo para una clasificación morfológica de artefactos líticos aplicada a estudios tecnológicos comparativos. Unpublished manuscript. Universidad de Buenos Aires, Buenos Aires.

Aschero, C.A., \& Hocsman, S. (2004). Revisando cuestiones tipológicas en torno a la clasificación de artefactos bifaciales. In A. Acosta, D. Loponte, \& M. Ramos (Eds.), Temas de Arqueología, Análisis Lítico (pp. 7-26). Buenos Aires: Universidad Nacional de Luján.

Barberena, R., Hajduk, A., Gil, A., Neme, G., Durán, V., Glascock, M.D., Giesso, M., Borrazzo, K., Pompei, M.P., Salgán, M.L., Cortegoso, V., Villarosa, G., \& Rughini A. (2011). Obsidian in the south-central Andes: Geological, geochemical, and archaeological assessment of north Patagonian sources (Argentina). Quaternary International, 245, 25-36. 
Beck, C., \& Jones, G. (2011). The role of mobility and exchange in the conveyance of toolstone during the Great Basin paleoarchaic. In R. Hughes (Ed.), Perspectives on prehistoric trade and exchange in California and Great Basin (pp. 55-82). Salt Lake City: University of Utah Press.

Binford, L.R., \& O'Connell, J. (1984). An Alyawara day: The stone quarry. Journal of Anthropological Research, 40, 3 , 406-432.

Bonomo, M.F., Lowry, J.P., Tykot, R.H., \& Gifford, J.A. (2014) An exploratory non-destructive analysis of two middle archaic greenstone pendants from Little Salt Spring, Florida, USA. Geoarchaeology, 29, 121-137.

Cortegoso, V., Neme, G., Giesso, M., Durán, V., \& Gil, A. (2012). El uso de la obsidiana en el sur de Mendoza. In A. Gil \& G. Neme (Eds.), Paleoecología humana en el sur de Mendoza (pp. 180-211). Buenos Aires: Sociedad Argentina de Antropología.

De Francesco, A.M., Durán, V., Bloise, A., \& Neme, G. (2006). Caracterización y procedencia de obsidianas de sitios arqueológicos del área natural protegida Laguna del Diamante (Mendoza, Argentina) con metodología no destructiva por fluorescencia de rayos (XRF). In V. Durán \& V. Cortegoso (Eds.), Arqueología y Ambiente de Áreas Naturales Protegidas de la Provincia de Mendoza (pp. 53-67). Anales de Arqueología y Etnología, 61.

Durán, V., Giesso, M., Glascock, M., Neme, G., Gil A., \& Sanhueza, L. (2004). Estudios de redes de aprovisionamiento y redes de distribución de obsidiana durante el Holoceno Tardío en el sur de Mendoza (Argentina). Estudios Atacameños, 28, 25-43.

Durán, V., de Francesco, A., Cortegoso, V., Neme, G., Cornejo, L., \& Bocci, M. (2012). Caracterización y procedencia de obsidianas de sitios arqueológicos del Centro Oeste de Argentina y Centro de Chile con metodología no destructiva por Fluorescencia de Rayos X (XRF). Intersecciones en Antropología, 13, 423-437.

Eerkens, J.W., Vaughn, K.J., Carpenter, T.R., Conlee, C.A., Grados, M.L., \& Schreiber, K. (2008). Obsidian hydration dating on the south coast of Peru. Journal of Archaeological Science, 35, 2231-2239.

Elston, R. G. (1992). Archaeological investigations at Tosawhi, a great basin quarry (Part 2). Nevada: Intermountain Research.

Garvey, R. (2012). Human behavioral responses to Middle Holocene climate changes in northern Argentine Patagonia. Unpublished doctoral dissertation, University of California, Davis.

Garvey, R. (2015). A model of lithic raw material procurement. In N. Goodale \& W. Andrefsky (Eds.), Lithic technological systems and evolutionary theory (pp. 156-171). Cambridge: Cambridge University Press.

Garvey, R., Carpenter, T., Gil, A., Neme, G., \& Bettinger, R. (2013). Provisional obsidian hydration rates for two northern Patagonian sources. Unpublished manuscript. Mendoza: Museo de Historia Natural de San Rafael.
Giesso, M., Durán, V., Neme, G., Glascock, M.D., Cortegoso, V., Gil, A., \& Sanhueza, L. (2011). A study of obsidian source usage in the Central Andes of Argentina and Chile. Archaeometry, 53, 1, 1-21.

Glascock, M.D., \& Ferguson, J.R. (2012). Report on the analysis of obsidian source samples by multiple analytical methods. Report on file at the Archaeometry Laboratory, University of Missouri-Columbia.

Glascock, M.D., Braswell, G.E., \& Cobean, R.H. (1998). A systematic approach to obsidian source characterization. In M.S. Shackley (Ed.), Archaeological obsidian studies: Method and theory (pp. 15-65). New York and London: Plenum Press.

Halstead, P., \& O'Shea, J. (1984). Introduction: Cultural responses to the risk and uncertainty. In P. Halstead \& J. O'Shea (Eds.), Bad years economics. New directions in archaeology (pp. 1-7). Cambridge: Cambridge University Press.

Hiscock, P. (2002). Quantifying the size of artifact assemblages. Journal of Archaeological Science, 29, 251-258.

Hughes, R. E. (1994). Intrasource chemical variability of artefact-quality obsidians from the Casa Diablo area, California. Journal of Archaeological Science, 21, 2, 263-271.

Ingbar, E. (1994). Lithic material selection and technological organization. In P. Carr (Ed.), The organization of North American prehistoric chipped stone technologies (pp. 45-56). Michigan: Archaeological Series 7.

King, J., Hildebrandt, W., \& Rosenthal, J. (2011). Evaluating alternative models for the conveyance of Bodie Hills obsidian into Central California. In R. Hughes (Ed.), Perspectives on prehistoric trade and exchange in California and Great Basin (pp. 148-170). Salt Lake City: University of Utah Press.

Moratto, M. (2011). Material conveyance in prehistoric California: Cultural context and mechanisms. In R. Hughes (Ed.), Perspectives on prehistoric trade and exchange in California and Great Basin (pp. 242-252). Salt Lake City: University of Utah Press.

Méndez, C., Gil, A., Neme, G., Delaunay, A., Cortegoso, V., Huidobro, C., Durán, V., \& Maldonado, A. (2015). Mid Holocene radiocarbon ages in the Subtropical Andes $\left(\sim 29^{\circ}\right.$ to $35^{\circ} \mathrm{S}$ ), climatic change and implications on human space organization. Quaternary International, 356, 15-26.

Nadooshan, F.K., Abedi, A., Glascock M.D., Eskandari, N., \& Khazaee, M. (2013). Provenance of prehistoric obsidian artefacts from Kul Tepe, northwestern Iran usin X-ray fluorescence (XRF) analysis. Journal of Archaeological Science, 40, 1956-1965.

Neme, G. (2007). Cazadores-Recolectores de Altura en los Andes Meridionales: El Alto Valle del Río Atuel. Oxford: British Archaeological Reports International Series 1591. 
Neme, G., \& Gil, A. (2008). Biogeografía humana en los Andes meridionales: Tendencias arqueológicas en el sur de Mendoza. Chúngara, Revista de Antropología Chilena, 40, $1,5-158$

Neme, G., \& Gil, A. (2009). Human occupation and increasing Mid-Holocene aridity. Current Anthropology, 50, 1, 149-163.

Neme, G., \& Gil, A. (Eds.) (2012). El registro arqueológico del sur de Mendoza en perspectiva biogeográfica. Paleoecología humana en el sur de Mendoza (pp. 255-279). Buenos Aires: Sociedad Argentina de Antropología.

Rogers, A. (2007). Effective hydration temperature of obsidian: A diffusion theory analysis of time-dependent hydration rates. Journal of Archaeological Science, 34, 656-665.

Rogers, A. (2009). An estimate of coso obsidian hydration rate, based on obsidian-radiocarbon pairings and the "weighted total least squares" method. International Association for Obsidian Studies Bulletin, 41, 9-20.

Rogers, A., \& Yohe, R. (2011). An improved equation for coso obsidian hydration dating, based on obsidian-radiocarbon association. Society of California Archaeology Proceedings, 25, 1-15.

Salgán, M.L. (2012). Organización tecnológica y biogeografía humana en La Payunia, sur de la Provincia de Mendoza. Unpublisheddoctoral dissertation, Universidad Nacional de La Plata, La Plata.
Salgán, M.L., Gil, A., \& Neme, G. (2012). Obsidianas en La Payunia (sur de Mendoza, Argentina): Patrones de distribución e implicancias en la ocupación regional. Magallania, 40, 1, 263-277.

Salgán, M.L, Gil, A., \& Neme, G. (2014). Movilidad, aprovisionamiento y uso de obsidiana en El Payén, sur de la provincia de Mendoza, Argentina. Comechingonia, 18, $1,33-50$.

Seelenfreund, A., Rees, C., Bird, R., Bailey, G., Bárcena, R., \& Durán, V. (1996). Trace element analysis of obsidian sources and artifacts of central Chile (Maule River Basin) and Western Argentina (Colorado River). Latin American Antiquity, 7, 7-20.

Shackley, M.S. (Ed.) (1998). Archaeological obsidian studies. Method and Theory. New York and London: Plenum Press.

Shackley, M.S. (2005). Obsidian: Geology and archaeology in the North American Southwest. Tucson: University of Arizona Press.

Summerhayes, G.R., Kennedy, J., Matisoo-Smith, E., Mandui, H., Ambrose, W., Allen, C., Reepmeyer, C., Torrence, R., \& Wadra, F. (2014), Lepong: A new obsidian source in the Admiralty Islands, Papua New Guinea. Geoarchaeology, 29, 238-248.

Tripcevich, N., Eerkens, J., \& Carpenter, T. (2012). Obsidian hydration at high elevation: Archaic quarrying at the Chivay source, southern Peru. Journal of Archaeological Science, 39, 1360-1367. 